\title{
Determination of ICT Competencies of Visual Arts Teachers at the Universidad del Atlántico - Virtual and Distance Education
}

\author{
By Giovanni Polifroni Lobo* \\ Carlos Beltrán Sánchez ${ }^{\dagger}$
}

The purpose of this research is to determine the ICT Competencies of Visual Arts teachers at University of Atlántico for Distance and Virtual Education. We also want to know what their perception is about the use of virtual learning environments in their educational work. This project will help teachers to go further in the generation of knowledge in order to develop new teaching skills with educational impact, so that students can learn through the appropriate use of ICT. Once the teachers are aware of their own ICT profile as they teach Visual Arts at the Fine Arts program at the Faculty of Fine Arts, they will be able to create new policies that support the appropriate use of technologies, as well as to create pedagogical models based on constructivist learning trends.

Keywords: Visual arts, e-learning, e-art, ICT skills, Teachers in Higher Education, Visual Arts, Art in 2d and 3d, instructional models, OVA, AVA, PLE.

\section{Introduction}

\section{Research Topic}

We need to know the ICT Competencies of Visual Arts Teachers from Universidad Del Atlántico for Distance and Virtual Education in order to teach contents in the Visual Arts Program. This will be useful to set standards of technological tools so that they can design their educational content.

\section{Statement of the Problem}

To have a clearer comprehension of this problem, we need to consider the challenge that many teachers face today as they make use of Information and Communication Technologies (ICT), knowing that they bear the greatest responsibility within the learning processes (Leal, 2008).

Distance education is the most renowned descriptor used when referencing distance learning. It often describes the effort of providing access

\footnotetext{
${ }^{*}$ Communications Coordinator and Lecturer Professor, Faculty of Fine Arts and the Faculty of Education, Research Department, Atlantic University, Colombia.

${ }^{\dagger}$ Professor Metropolitan University, Colombia.
} 
to learning for those who are geographically distant. During the last two decades, the relevant literature shows that various authors and researchers use inconsistent definitions of distance education and distance learning. As computers got involved in the delivery process of education, it was proposed a definition, which identified the delivery of instructional materials, using both print and electronic media (Moore, 1990).

Electronic learning, or e-learning, is the education based on modern methods of communication including the computer and its networks, various audio-visual materials, search engines, electronic libraries, and websites, whether accomplished in the classroom or at a distance. Generally speaking, this type of education is delivered through the World Wide Web where the educational institution makes its programs and materials available on a special website in such a manner that students are able to use them and interact with them easily through closed or shared networks, Internet, via email and online discussion groups (ICDE, n.d.).

Ellis (2004) disagrees with authors like Nichols (2003) who define eLearning as strictly accessed using technological tools that are web-based, web-distributed, or web-capable. To the contrary Ellis believe that e-Learning not only covers content and instructional methods delivered via CD-ROM, Internet or Intranet (Benson et al., 2002; Clark, 2002) but also includes audioand videotape, satellite broadcast and interactive TV. Tavangarian Tavangarian, Leypold, Nölting, Röser, and Voigt (2004) included the constructivist theoretical model as a framework for their definition by stating that eLearning is not only procedural but also shows some transformation of an individual's experience into the individual's knowledge through the knowledge construction process (İşman, 2011).

Virtual worlds are emerging as the new frontier in the use of ICTs for the engagement of students in primary, secondary and tertiary education. In 2010 the use of the virtual world, Second Life, was trialed as a pedagogical tool in the training of Visual Art Education students of University of Atlántico (Jacka, 2010)

Faced with this scenario, the promotion of a virtual context to help students become more competitive as they confront the various demands of today's society, both in their professional and personal life (Morales, 2011), promises a very positive horizon. Here, it is necessary to promote initiatives that aim at improving the depth and the generation of online knowledge and in the application of appropriate contexts for the pedagogical work of teachers. This will be carried out with a full understanding of teachers' attitudes, perceptions and their use of ICT competencies, in order to determine their influence on innovation processes exercised among members of this professional group (Prendes, Gutiérrez and Castañeda, 2010).

The training program for virtual teachers taught by on-line teachers at University of Atlántico is still in process. We can see, for example, that the creation and design of educational content as well as the implementation of supporting technology, both hardware and software, is limited. All these factors prevent research teachers from generating and proposing new virtual 
projects Also, there is not a clear concept in the University of what Distance Education is.

We need skilled teachers, with a multidisciplinary approach in digital repositories, e-learning, design of advanced websites, web 3.0, databases, instructional design for the creation of virtual subjects and presentation of scientific articles for diffusion of research projects in Distance Education. This would have a significant impact on the students' community and therefore on the general community for the generation and creation of knowledge. The most common constraints in Distance Education are the limited access to internet and the lack of knowledge of foreign languages, since various contents of e-learning education are in English and, to a much lesser extent, French.

Virtual worlds provide a simulated environment in which participants can interact with objects, their surroundings and each other using both asynchronous and synchronous communication media. They are used for gaming, education, socializing, medical, entertainment and creative pursuits. There are many virtual worlds available through online interfaces including the popular Multi User Virtual Environment (MUVE) game, World of Warcraft and Linden Lab's SL. The latter is a 3D simulation environment in which participants have $24 \mathrm{hr}$ access to the online environment in which they can inhabit and interact (Jacka, 2010).

There are many ways that virtual worlds can be used in education. Ryan (2008) outlines 16 ways to use virtual worlds in the classroom. They include: adding a visual element, as an interactive library, a connection device, role playing device, simulation device, games for learning, soft skill development, research, virtual tourism and field trips, social device, to create anonymity, machinima, recruitment, build awareness and/or promote an event, learn how to build and as an open learning environment. One of the key questions is how do we teach in virtual worlds? What new strategies do we need to be able to present the relevant content and to engage our learners? When you first use a virtual world either as a teacher or student you are presented with something very unfamiliar. It is by default that we try to replicate the way that we are most comfortable with in trying to develop quality experiences for our students.

Emergent research advocates that we should be looking for new models of teaching and learning in virtual world environments (Ryan, 2008; Peachey, Gillen, Livingstone \& Smith- Robbins 2010; Knapp \& O'Driscoll, 2010). The experience of the initial utilization of this educational technology confirms that virtual worlds have a role in Visual Arts Education.

As effective instruction is considered the instruction which enables students to acquire specified skills, knowledge and attitudes (Reiser \& Dick, 1996). During the effective instruction, students can be motivated well. To motivate students in the instruction process, all factors must be determined well. During determination process, there are four important principles that play a key role. These principles are listed below: 
1. Begin the planning process by clearly identifying the general goals and specific objectives students will be expected to attain;

2. Plan instructional activities that are intended to help students attain those objectives;

3. Develop assessment instruments which can measure the attainment of those objectives;

4. Revise instruction in light of student performance on each objective and student attitudes towards instructional activities (Reiser \& Dick, 1996).

Teachers should follow these principles in order to apply successfully their instruction.

At the end of this process, it can be seen the student learning performance in instructional activities based on defined goals and objectives. Instructional design pays attention to the instruction from the learner perspective rather than from the content perspective which is a traditional approach.

It is also important to consider the need for a preparation of the ITC sector in Colombia in order to address the challenges originated by the development of technological, institutional and market convergence. This implies the proposal of a new balance between the promotion of competitive development of the sector and the fulfillment of social goals such as the increase of ICT coverage and access for citizens, companies and public institutions, which is a result of the public nature of telecommunications (Guerra \& Oviedo 2011).For the students, this impact will result in great development, since it promotes their cognitive abilities, their autonomy to do and present their own tasks in an individual and organized manner, and it increases their creativity and practice of Visual Arts ownership.

\section{Objectives}

\section{Purpose of this Study}

The purpose of this research is to determine the ICT Competencies of Visual Arts teachers at University of Atlántico for Distance and Virtual Education. We also want to investigate their perception about the use of virtual learning environments in their educational work.

This project will help teachers to go further in the generation of knowledge in order to develop new teaching skills with educational impact, so that students can learn through the appropriate use of ICT. Once the teachers are aware of their own ICT profile as they teach Visual Arts at the Fine Arts program at the Faculty of Fine Arts, they will be able to create new policies that support the appropriate use of technologies, as well as to create pedagogical models based on constructivist learning trends for virtuality. 


\section{Research Questions}

What are the ICT competencies that Teachers from the Fine Arts Program at the Fine Arts School (of University of Atlántico) have in terms of utility and implementation of ICT in their teaching skills?

What is the perception that teachers from the Fine Arts Program at University of Atlántico have about the utility and implementation of ICT to go further and generate knowledge within the required contents and contexts for the development of their pedagogical practices?

\section{Terms and Definitions}

ICT. Conceptual and theoretical tools, supports and channels that process, store, synthesize, retrieve and present information in the most varied forms.

Personal Learning Environment. PLEs integrate different tools for virtual training, social networking and mentoring, among others, to reach an autonomous, creative and cooperative learning process.

Visual Arts. This concept refers to the various expressions of art whose products are primarily visual in nature, including traditional arts, and incorporates new forms of expression arising from technological progress, that is, the so-called new media.

\section{Methodology}

\section{Type of Research}

This is a quantitative research. It is part of the empirical-positivist paradigm and is both explanatory and descriptive, apart from the fact that it seeks to identify a set of factors that influence this perception. The project is focused on the qualities that teachers from the Fine Arts Program at the School of Fine Arts have, in terms of the utility and implementation of ICT in their teaching. Also, this research wants to know their perception about the use and implementation of ICT in their work, in the creation of knowledge, and in the content and context required for the progress of their teaching practices, based on ICT Competencies (UNESCO, 2008).

\section{Variables}

Some of the variables and categories that will help us to measure and to evaluate the required information for the design of a virtual space of collaboration as the one we are proposing in this project will be:

- The ICT Competencies of Visual Arts teachers. 
- The perception and significance of ICT in Visual Arts teachers' skills.

The variables or categories presented here, as well as other ideas considered during the implementation of this project, will be oriented to address each of the questions of the research, which are significant to achieve the above mentioned purpose.

The concepts that will be considered as variables and the categories with which will be examined the perception of the final user of the virtual classrooms, proposed by the University are the followings:

1. Content Relevance.

2. Agility of the virtual space.

3. Speed of the virtual space.

4. Appropriate design of the virtual space.

5. Usefulness of contents posted in the virtual space.

\section{Participants}

Our choice of the geographical area in which this project is developed is based on the criteria that are exposed in the framework of this project is: The purpose of this research is to determine the ICT Competencies of Visual Arts teachers at University of Atlántico for Distance and Virtual Education. We also want to investigate their perception about the use of virtual learning environments in their educational work. This project will help teachers to go further in the generation of knowledge in order to develop new teaching skills with educational impact, so that students can learn through the appropriate use of ICT and it is considered as a methodological guide for the development of the questions raised here, that means, the group of teachers from the Fine Arts program at University of Atlántico. Teachers with Master Degrees, adults, who teach on-line Visual Arts classes.

\section{Study Population and Sample}

The project will focus on Visual Arts teachers from the Faculty of Fine Arts at University of Atlántico. As for the sample design, we will use the respective procedure criteria aimed to the achievement of the project.

Part of the information that will be gathered for the project will be taken from this thesis, based on a sample group of 35 teachers out of the 63 existing in the Fine Arts program at University of Atlántico, considering the Cluster Sample Design. The selection of this group will be taken from one of the databases of the Fine Arts Faculty, with prior permission of the Dean of the Department, in order to use the instrument randomly through an online survey. 


\section{Instruments}

In order to answer the questions of the research, we will use a survey designed according to the surveys conducted in the methodological guide of a project funded by Colciencias under the call 578 with the title: "Measuring the Impact of Activities Promoting ICT in Education in the Colombian Caribbean Region." Case of Barranquilla and Cartagena, by University of Norte and Technological University Tecnológica of Bolívar, (Hung, 2013).

\section{Procedures}

1. Get in contact with the Fine Arts Program Coordinator in order to explain the importance of the project.

2. Request due authorization for the implementation of the instrument within the population.

3. Write a letter to the teachers, expressing the importance of the project and embedding the instrument that will be applied.

4. The instrument will be designed following the format found in the tools catalog of Google Docs, called Online Form, which allows to design the questions, save the data in Excel tables, export them and process them with SPSS, a statistical software program.

5. Teachers will answer the survey, filling out each of the items online or via e-mail.

6. After the collection of the data we will proceed to the processing of the data through SPSS.

\section{Method for Data Analysis}

Once the data is imported into SPSS, we will design the first percentage descriptive analysis, using the software, based on the results of the questionnaire, measuring the teachers' associated factors that may affect their use of ICT as a teaching and learning tool at University of Atlántico.

Later, we will design a data-mining plan, which means that we will create a conceptual framework, specifying the dependent and independent variables according to the survey and then determine, by means of observations, the perceptions and profile of teachers in terms of their use of ICT competencies, as are defined by UNESCO (2008).

\section{Results from Data Analysis}

The results that we obtained from the survey conducted among the Visual Arts Teachers of University of Atlántico, shown below, in order to determine their ICT Competencies and their perception in terms of their use of technology when teaching pedagogical contents. 
ICT Competencies that the Teachers from the Faculty of Fine Arts have in terms of the Utility and Implementation of ICT in their Educational Skills (Instrument of survey determined by the UNAD Florida to find the mentioned Investigation in 2014).

$100 \%$ of teachers surveyed indicated that during the 2014 they have attended a training course for the use of ICT. As for the type of training that they have received, the figure 1 shows that $71 \%$ of Visual Arts Teachers from University of Atlántico have attended Seminars and Conferences in recent years, 25\% has followed Postgraduate Studies (Specialization, Master and $\mathrm{PhD}$ ) and $4 \%$ has participated in short courses and/or diploma (one semester or less), with technologies support.

Figure 1. Type of Training that the Surveyed Teachers have Received.

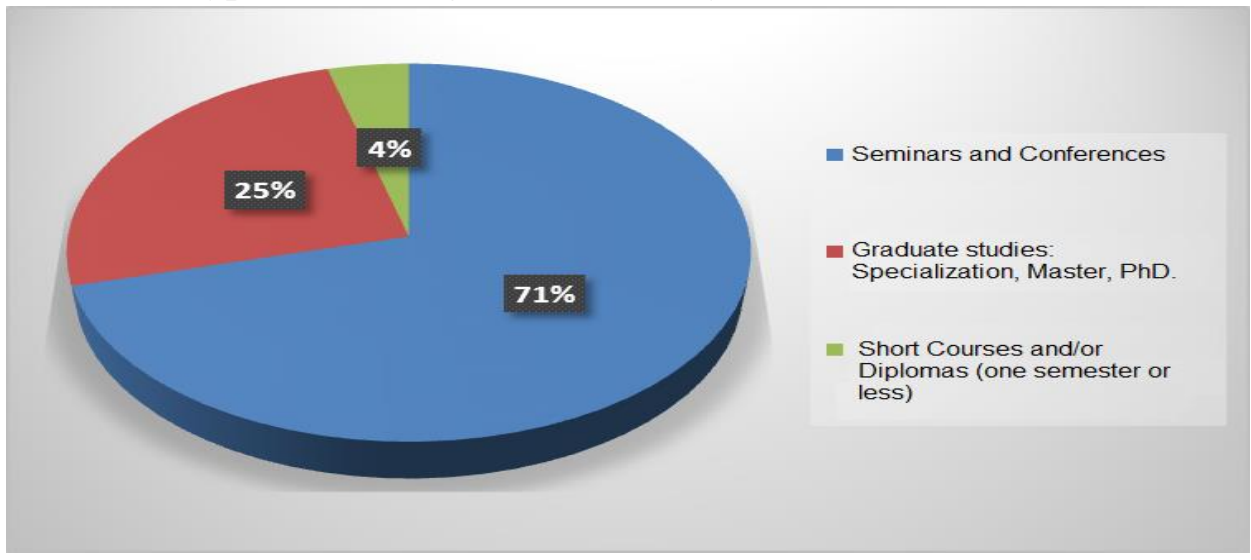

Meanwhile, as we can see in Table 1, referring to the last course taken by teachers, $41,67 \%$ of them claimed to have taken courses on their own initiative, $29.17 \%$ by initiative of the school, $16.67 \%$ by Initiative of the Department of Education and $12.50 \%$ by initiative of the National Ministry of Education.

Table 1. Courses Taken by Teachers

\begin{tabular}{|c|c|c|}
\hline \multicolumn{3}{|l|}{ Courses taken by teachers } \\
\hline & Frequency & Percentage (\%) \\
\hline On their own initiative & 10 & 41.67 \\
\hline By school's initiative & 7 & 29.17 \\
\hline $\begin{array}{l}\text { By initiative of the } \\
\text { Department of Education }\end{array}$ & 4 & 16.67 \\
\hline $\begin{array}{l}\text { By initiative of the National } \\
\text { Ministry of Education }\end{array}$ & 3 & 12.50 \\
\hline Total & 24 & 100 \\
\hline
\end{tabular}

Table 2 shows that $16.67 \%$ explores and reflects on the use of ICT for the students learning needs when evaluating their professional performance, growth and leadership, and $12.50 \%$ continuously explores and discusses about the benefits of digital learning communities in order to improve their 
teaching experience with their students.

Table 2. Evaluation of Teachers Performance

\begin{tabular}{|l|l|l|}
\hline Options & Frequency & $\begin{array}{l}\text { Percent } \\
\text { age (\%) }\end{array}$ \\
\hline $\begin{array}{l}\text { I continuously explore and discuss on the benefits } \\
\text { of digital learning communities to improve my } \\
\text { teaching experience with my students. }\end{array}$ & 3 & 12,50 \\
\hline $\begin{array}{l}\text { I make use of digital learning communities aimed } \\
\text { at taking advantage of ICT for a better learning } \\
\text { process with my students. }\end{array}$ & 1 & 4,17 \\
\hline $\begin{array}{l}\text { c. I have helped to develop or maintain learning } \\
\text { communities to increase ideas and methods to } \\
\text { strengthen the learning process of my students. }\end{array}$ & 1 & 4,17 \\
\hline $\begin{array}{l}\text { d. I recognize and evaluate perspectives on the use } \\
\text { of ICT and the skills required for it. }\end{array}$ & 2 & 8,33 \\
\hline $\begin{array}{l}\text { e. I have implemented actions to ensure the } \\
\text { adoption of ICT in my school. }\end{array}$ & 1 & 4,17 \\
\hline $\begin{array}{l}\text { f. I have a shared vision of a good appropriation of } \\
\text { ICT in the educational environment, working } \\
\text { collaboratively with others in decision- making; } \\
\text { and I help others in the development of their } \\
\text { leadership and ICT competences. }\end{array}$ & 1 & 4,17 \\
\hline $\begin{array}{l}\text { g. I explore and reflect on the use of ICT for the } \\
\text { students' learning needs. }\end{array}$ & 4 & 4,17 \\
\hline $\begin{array}{l}\text { h. I regularly evaluate and reflect on current } \\
\text { research trends and good practices on how to use } \\
\text { ICT for learning. }\end{array}$ & 1 & 4,17 \\
\hline $\begin{array}{l}\text { i. I have contributed to the development of } \\
\text { activities oriented to an effective use of ICT in } \\
\text { order to enhance teaching and learning, and I have } \\
\text { shared them in learning communities or other } \\
\text { scenarios at a local, national or global level. }\end{array}$ & 1 & 4,67 \\
\hline $\begin{array}{l}\text { j. I have shown, discussed and socialized among } \\
\text { different members of the educational community } \\
\text { where I work and in general, the impact of ICT on } \\
\text { my students' learning process and on my } \\
\text { professional development as a teacher. }\end{array}$ & 1 & \\
\hline
\end{tabular}

Table 3 shows that $75 \%$ of teachers give a higher punctuation to activities or actions such as searching and selecting information using different ICT tools and sources such as search engines, virtual libraries, repositories, etc., for the development of learning activities with their students; and they gave a lower punctuation (12.50\%) to the use of mobile applications (apps). 
Table 3. Activities Developed by Teachers

\begin{tabular}{|c|c|c|c|}
\hline \multirow{2}{*}{ Activities or Actions } & \multicolumn{3}{|c|}{ PERCENTAGE (\%) } \\
\hline & LOW & MEDIUM & HIGHT \\
\hline $\begin{array}{l}\text { a. Find and select information using } \\
\text { different ICT tools and sources such as } \\
\text { search engines, virtual libraries, repositories, } \\
\text { etc. }\end{array}$ & 12,50 & 12,50 & 75,00 \\
\hline $\begin{array}{l}\text { b. Communicate with others using ICT such } \\
\text { as via email, chat forums, text messages, } \\
\text { etc. }\end{array}$ & 4,17 & 16,67 & 79,17 \\
\hline $\begin{array}{l}\text { c. Moderate learning networks and virtual } \\
\text { communities such as Colombia Aprende, } \\
\text { Renata, Educavirtual etc. }\end{array}$ & 12,50 & 70,83 & 16,67 \\
\hline $\begin{array}{l}\text { d. Participate in virtual communities and } \\
\text { learning networks like Colombia Aprende, } \\
\text { Renata, Educavirtual, etc. }\end{array}$ & 16,67 & 66,67 & 16,67 \\
\hline $\begin{array}{l}\text { c. Search, select and use digital educative } \\
\text { resources. }\end{array}$ & 4,17 & 12,50 & 83,33 \\
\hline $\begin{array}{l}\text { d. Design learning environments that } \\
\text { incorporate the use of ICT and virtual } \\
\text { courses, networking etc. }\end{array}$ & 8,33 & 16,67 & 75,00 \\
\hline $\begin{array}{l}\text { e. Produce digital educational resources } \\
\text { such as audio, video, online presentations, } \\
\text { etc. }\end{array}$ & 12,50 & 12,50 & 75,00 \\
\hline $\begin{array}{l}\text { f. Post their own digital educational } \\
\text { resources on sites like Wordpress, BlogSpot } \\
\text { etc. }\end{array}$ & 12,50 & 70,83 & 16,67 \\
\hline $\begin{array}{l}\text { g. Use the rules of intellectual property and } \\
\text { licensing for the use of private and other } \\
\text { people's information. }\end{array}$ & 33,33 & 29,17 & 37,50 \\
\hline $\begin{array}{l}\text { h. Exchange learning experiences and/or } \\
\text { research in educational use of ICT. }\end{array}$ & 16,67 & 54,17 & 29,17 \\
\hline $\begin{array}{l}\text { i. Use ICT to support research processes in } \\
\text { relation to the use of specialized databases, } \\
\text { or publication of results from the research. }\end{array}$ & 16,67 & 62,50 & 20,83 \\
\hline $\begin{array}{l}\text { j. Use of mobile devices (phone and tablets) } \\
\text { to develop their teaching experience with } \\
\text { their students. }\end{array}$ & 58,33 & 20,83 & 20,83 \\
\hline $\begin{array}{l}\text { k. Invigorate the processes of teaching and } \\
\text { learning, using visual aids such as TV and } \\
\text { radio. }\end{array}$ & 8,33 & 12,50 & 79,17 \\
\hline $\begin{array}{l}\text { 1. Use of mobile applications (apps) for the } \\
\text { development of learning activities with their } \\
\text { students. }\end{array}$ & 66,67 & 20,83 & 12,50 \\
\hline
\end{tabular}

The data in Table 4 shows that $54.8 \%$ of teachers surveyed, have as a main objective the availability of attractive and dynamic learning environments, $51.2 \%$ think that the main objective is to develop in students the skills to search 
and select information and $44.6 \%$ think that the main objective is the development of thinking processes in students for skills training.

Table 4. Teacher Objectives

\begin{tabular}{|l|l|}
\hline OBJECTIVE & YES (\%) \\
\hline a. To develop students skills to search and select information & 51.2 \\
\hline b. To promote students interaction in collaborative environments. & 34.2 \\
\hline c. To have attractive and dynamic learning environments. & 54.8 \\
\hline d. To facilitate the comprehension of disciplinary content. & 42.7 \\
\hline e. To develop thinking processes in students for training in skills. & 44.6 \\
\hline $\begin{array}{l}\text { f. To promote classroom projects that encourage creativity and } \\
\text { innovation. }\end{array}$ & 38.3 \\
\hline
\end{tabular}

Meanwhile, in Figure 2 we can see that $70,8 \%$ of teachers participate in virtual communities or networks oriented to their role as teachers, but $29,2 \%$ of teachers do not.

Figure 2. Participation of Teachers in Virtual Communities

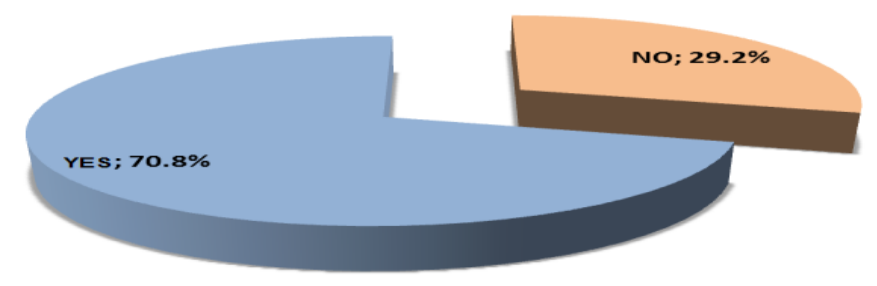

In relation to their teaching activities by means of ICT in collaborative work in the classroom, $97.1 \%$ of teachers said that they have used Skype Chat and $93.4 \%$ Video calls (see Table 5).

Table 5. Activities Using Technologies for Collaborative Works in the Classroom

\begin{tabular}{|c|c|c|}
\hline \multirow{2}{*}{$\begin{array}{l}\text { Technologies used for communication } \\
\text { and collaborative learning }\end{array}$} & \multicolumn{2}{|c|}{ Percentage $(\%)$} \\
\hline & YES & NO \\
\hline a) $\quad$ Virtual courses & 85.2 & 14.8 \\
\hline Video calls & 93.4 & 6.6 \\
\hline Video streaming & 92.8 & 7.2 \\
\hline d) Virtual Office & 75.3 & 24.7 \\
\hline e) Skype Chat & 97.1 & 2.9 \\
\hline f) Digital Repositories & 32.7 & 67.3 \\
\hline g) E-books & 79.6 & 20.4 \\
\hline
\end{tabular}

Table 6 shows that $95.5 \%$ of teachers have used Adobe Photoshop CS5 
and $82.1 \%$ have used Adobe Illustrator CS5 as tools for design Visual Arts pieces in the Classroom. The less used software is Unity 3D Engine, with a $7.8 \%$.

Table 6. Activities with Communication Technologies for design Visual Arts pieces in the Classroom

\begin{tabular}{|c|c|c|}
\hline \multirow{2}{*}{ Software Tools } & \multicolumn{2}{|c|}{ Percentage (\%) } \\
\hline & YES & NO \\
\hline a) $\quad$ Adobe Illustrator Cs5 & 82,1 & 17,9 \\
\hline b) Adobe Photoshop Cs5 & 95,5 & 4,5 \\
\hline c) 3d Max AutoDesk 2013 & 22,6 & 77,4 \\
\hline d) Unity 3d Engine & 7,8 & 92,2 \\
\hline e) Artrage & 8,9 & 91,1 \\
\hline f) $\quad$ Adobe Flash Cs5 & 15,4 & 84,6 \\
\hline g) Adobe Premiere Pro & 20,3 & 79,7 \\
\hline
\end{tabular}

Perception that teachers from the Fine Arts Program at University of Atlántico have about the utility and implementation of ICT to deepen and generate knowledge within the required contents and contexts for the development of their pedagogical practices.

According to Table 7, 70.2\% of teachers think that they use ICTs because these tools promote students' participation, and 51.2\% use them because they facilitate the process of students' knowledge generation.

Table 7. Reasons why Teachers Use ICT in their Teaching

\begin{tabular}{|l|l|l|}
\hline \multirow{2}{*}{ Reasons (ROTAR) } & \multicolumn{2}{l|}{ Percentages (\%) } \\
\cline { 2 - 3 } & Yes & No \\
\hline $\begin{array}{l}\text { a. Depending on the availability of resources in the } \\
\text { school. }\end{array}$ & 14,0 & 86,0 \\
\hline $\begin{array}{l}\text { b. To articulate my teaching practice with institutional } \\
\text { guidelines (PEI). }\end{array}$ & 19,8 & 80,2 \\
\hline $\begin{array}{l}\text { c. Because they are tools that motivate student } \\
\text { participation }\end{array}$ & 70,2 & 29,8 \\
\hline $\begin{array}{l}\text { d. Because they facilitate the process of student's } \\
\text { knowledge generation. }\end{array}$ & 51,2 & 48,8 \\
\hline \begin{tabular}{l} 
use it strengthens the work opportunities for students. \\
\hline $\begin{array}{l}\text { f. Because enrich the evaluation and monitoring of } \\
\text { learning processes. }\end{array}$
\end{tabular} & 28,1 & 84,7 \\
\hline $\begin{array}{l}\text { g. Because they provide different ways to present } \\
\text { information. }\end{array}$ & 18,2 & 81,8 \\
\hline $\begin{array}{l}\text { h. Because ICT supports and energize the research } \\
\text { process. }\end{array}$ & 28,1 & 71,9 \\
\hline i. I do not use them at all. & 4,1 & 95,9 \\
\hline
\end{tabular}

According to Table $8,71.1 \%$ of teachers validated the use of ICT to evaluate and use sources of information for research and learning, while $38 \%$ 
use a wide variety of environments and digital resources for students to collaborate with others, regardless of the distance separating them.

Table 8. Teachers Validation of ICT to Evaluate the Use of Information Sources for Research

\begin{tabular}{|c|c|c|}
\hline \multirow[t]{2}{*}{ Options } & \multicolumn{2}{|l|}{ Percentage (\%) } \\
\hline & $\begin{array}{l}\text { Never } \\
\text { Sometimes }\end{array}$ & $\begin{array}{l}\text { Often } \\
\text { Always }\end{array}$ \\
\hline $\begin{array}{l}\text { a. I identify the appropriate equipment and } \\
\text { ICT resource that is most suitable for the } \\
\text { development of particular activities and I } \\
\text { plan activities oriented to such purposes. }\end{array}$ & 37,2 & 62,8 \\
\hline $\begin{array}{l}\text { b. I make plans and facilitate the } \\
\text { understanding and use of ICT resources and } \\
\text { equipment that is most suitable for the } \\
\text { particular learning experience of my } \\
\text { students. }\end{array}$ & 41,3 & 58,7 \\
\hline $\begin{array}{l}\text { c. I select and adjust the resources and ICT } \\
\text { equipment for the development of learning } \\
\text { activities for the knowledge transfer to new } \\
\text { technologies and situations. }\end{array}$ & 45,5 & 54,5 \\
\hline $\begin{array}{l}\text { d. I develop activities oriented to engage } \\
\text { students in collaborative exploration of } \\
\text { emerging technologies and their use in real- } \\
\text { life situations. }\end{array}$ & 52,9 & 47,1 \\
\hline $\begin{array}{l}\text { e. I recognize the use of ICT resources and } \\
\text { equipment for the development of } \\
\text { communication and collaboration activities } \\
\text { with my students. }\end{array}$ & 29,8 & 70,2 \\
\hline $\begin{array}{l}\text { f. I make use of a wide variety of } \\
\text { environments and digital resources for my } \\
\text { students to collaborate with others } \\
\text { regardless of the distance separating them. }\end{array}$ & 62,0 & 38,0 \\
\hline $\begin{array}{l}\text { g. I test and use a variety of ICT to } \\
\text { communicate and exchange information } \\
\text { with people from other parts of the world. }\end{array}$ & 47,9 & 52,1 \\
\hline $\begin{array}{l}\text { h. I recognize the use of ICT to identify, } \\
\text { evaluate and use information sources for } \\
\text { research and learning. }\end{array}$ & 28,9 & 71,1 \\
\hline $\begin{array}{l}\text { i. I demonstrate by means of ICT tools how } \\
\text { effective these resources can be to find } \\
\text { sources of information that support } \\
\text { research, and both my learning process and } \\
\text { that of my students. }\end{array}$ & 35,5 & 64,5 \\
\hline $\begin{array}{l}\text { j. I promote the effective use of ICT tools to } \\
\text { identify and select information to help } \\
\text { research and personal learning both for me } \\
\text { and for my students. }\end{array}$ & 39,7 & 60,3 \\
\hline
\end{tabular}


According to Table 9, we can see that $89.18 \%$ of surveyed teachers agree with the fact that ICT is an important tool in their professional life. On the other hand, most of them disagree $(27.22 \%)$ with Students are more prepared than me in terms of ICT usage.

Table 9. Teachers Opinion on the Importance of ICT

\begin{tabular}{|l|l|l|l|}
\hline \multirow{2}{*}{ Assertions (ROATE) } & \multicolumn{2}{l|}{ Percentage (\%) } \\
\cline { 2 - 4 } & Disagree & Irrelevant & Agree \\
\hline $\begin{array}{l}\text { a. ICT has helped me to transform ways } \\
\text { of communication and social relationships. }\end{array}$ & 12,9 & 6,46 & 80,64 \\
\hline $\begin{array}{l}\text { b. The use of ICT is an answer to } \\
\text { consumerism demands. }\end{array}$ & 14,55 & 9,77 & 75,68 \\
\hline c. ICT is an institutional demand. & 21,71 & 14,45 & 63,84 \\
\hline $\begin{array}{l}\text { d. I am interested in receiving training on } \\
\text { ICT use. }\end{array}$ & 3,81 & 8,94 & 87,25 \\
\hline $\begin{array}{l}\text { e. Students are more prepared than me in } \\
\text { terms of ICT usage. }\end{array}$ & 27,22 & 8,39 & 64,39 \\
\hline $\begin{array}{l}\text { f. It is important to be updated in terms of } \\
\text { the pedagogical use of ICT. }\end{array}$ & 2,71 & 8,66 & 88,63 \\
\hline $\begin{array}{l}\text { g. I feel comfortable participating in } \\
\text { virtual learning environments. }\end{array}$ & 5,19 & 10,32 & 84,5 \\
\hline $\begin{array}{l}\text { h. The use of ICT improve the academic } \\
\text { performance of students. }\end{array}$ & 7,11 & 9,77 & 83,12 \\
\hline $\begin{array}{l}\text { i. ICT are an important tool in my } \\
\text { professional life. }\end{array}$ & 4,91 & 5,91 & 89,18 \\
\hline $\begin{array}{l}\text { j. I would read in a computer rather than a } \\
\text { book or printed copy. }\end{array}$ & 47,88 & 16,65 & 35,46 \\
\hline
\end{tabular}

In addition to that, $90.9 \%$ of teachers use mechanisms of evaluation for their students, and $89.4 \%$ promote new learning environments and creativity among students (Table 10). 
Table 10.Teachers Use of Devices and ICT Resources

\begin{tabular}{|l|l|l|}
\hline \multirow{2}{*}{ Reasons } & \multicolumn{2}{l|}{ Percentage (\%) } \\
\cline { 2 - 3 } & YES & NO \\
\hline $\begin{array}{l}\text { To improve their professional practices with their } \\
\text { students. }\end{array}$ & 12.6 & 87.4 \\
\hline $\begin{array}{l}\text { To promote collaborative contexts among their } \\
\text { students. }\end{array}$ & 41.3 & 58.7 \\
\hline $\begin{array}{l}\text { To promote the use of resources oriented to research } \\
\text { and learning experiences among their students. }\end{array}$ & 25.8 & 74.2 \\
\hline $\begin{array}{l}\text { To promote alternative contexts of communication } \\
\text { among their students. }\end{array}$ & 34.7 & 65.3 \\
\hline To reinforce the contents taught in the classroom. & 87.5 & 12.5 \\
\hline To promote enriched learning contexts. & 85.8 & 14.2 \\
\hline $\begin{array}{l}\text { To promote new learning contexts and creativity } \\
\text { among their students. }\end{array}$ & 89.4 & 10.6 \\
\hline To find mechanisms of evaluation for their students. & 90.9 & 9.1 \\
\hline $\begin{array}{l}\text { To facilitate the resolution of complex problems } \\
\text { related to the subject that is taught. }\end{array}$ & 26.7 & 73.3 \\
\hline $\begin{array}{l}\text { To promote creative and innovative thinking among } \\
\text { their students. }\end{array}$ & 55.8 & 44.2 \\
\hline
\end{tabular}

\section{Discussion, Conclusions and Recommendations}

In this chapter, we will discuss the results of the research, which are mainly focused on teachers' opinions on ICT competencies and their perception on the use of technologies for their educational contents. Then, we will establish conclusions and recommendations based on the study.

\section{Discussion}

As for the question about the ICT Competencies of Teachers from the Fine Arts Program regarding the usefulness and implementation of ICT in their teaching skills, the following results were obtained:

According to Table 2, when teachers evaluate their own performance, they consider the use of ICT as an enabling tool for teaching and learning processes. They also explore and discuss continuously about the benefits of digital learning communities in order to improve their work as teachers. The overall results also show that there is a significant recognition among teachers of the benefits of using ICT, and how these should be integrated into learning plans and research. It is also evident in Table 2 that teachers identified ICT as part of their strategies and as a tool to improve their professional performance.

All this self-evaluation obtained by teachers about their performance is useful for their competencies, because the results show a high score from teachers in terms of to the usefulness and implementation of ICT in teaching 
and learning processes.

Meanwhile, the data obtained from Table 3 shows that teachers assign a higher rate to activities or actions related to: search and selection of information by means of different ICT tools, design of learning environments that incorporate the use of ICT and produce digital resources. Similarly, the revitalization of teaching and learning processes, using visual aids such as $\mathrm{TV}$, radio and digital resources to establish communication with others, using ICT through email, chat forums, text messages, etc.

As for the activities with a lower rate, teachers chose the publication of posts on websites like wordpress, BlogSpot, and the use of mobile applications for the development of learning activities with their students.

The results demonstrate that the teachers surveyed have a basic knowledge of virtual tools. These findings have consequences in the competencies of Visual Arts teachers, because they have a hard time carrying out research projects supported by technologies to generate innovation and develop creative teaching processes in class.

Regarding the activities in communication technologies for collaborative work in Visual Art classes, Table 6 shows that teachers prefer the implementation of Adobe Photoshop and Adobe Illustrator CS5, being the two most popular programs for graphic design within the Internet technology.

Due to the perception that teachers from the Fine Arts program at University of Atlántico have in terms of the implementation of ICT to generate contents and contexts to develop their teaching activity, the following results are discussed:

As we see in Table 7 regarding the reasons that teachers have to use ICT in their teaching, we found that most of them believe that ICT are tools to motivate students' participation; another group of teachers believes that ICT facilitate students' knowledge construction. And finally, we can see also the perception of teachers of the fact that these tools support and stimulate the research process.

This information corroborates teachers' perceptions on the high value and importance of the use of these technological tools to strengthen educational processes, and how ICT are valuable to spread and show several forms of Arts by means of education.

In Table 9, we see that the majority of teachers agree with receiving training for the use of ICT, as they consider them as important in their professional and personal life. They also see as positive their participation in virtual learning environments, and consider that ICT resources are necessary and attractive to students.

In terms of the perception of teachers on the importance of ICT application, they consider that these resources are beneficial to the educational processes, as the majority say, and these technological resources transform communication and social relations; in other words, ICT are beneficial both inside and outside the classroom.

In terms of teachers use of ICT equipment and resources, the data collected in Table 10, show that most teachers use these resources for 
mechanisms of evaluation to their students, to promote new learning environments and creativity among students. In addition, they use them to strengthen the contents in class, promoting a better use of resources, and creating a richer learning environment.

According to the survey, Visual Arts teachers are aware of and recognize the importance of ICT in the educational process. They see them as technological tools to support their courses and strengthen their teaching skills; however, the results of the survey show a disadvantageous aspect for teachers. They have a lack of knowledge to create or propose activities for the development of research projects supported by technology, and to certain virtual tools to support their collaborative work in class.

\section{Conclusion}

We conclude that Visual Arts teachers from University of Atlántico have knowledge of ICT competencies for Virtual Education, but they do not use them because they ignore their functions. In addition to that, they do not engage in collaborative work online with other students, or do not take virtual education courses.

Teachers from the Faculty of Fine Arts have over 20 to 30 years of experience in classroom teaching. This fact makes it difficult for them to learn new Information and Communication Technologies - ICT.

In the Faculty of Fine Arts at University of Atlántico, teachers are used to creating educational material for classroom teaching, but they usually support this material with traditional pedagogical tools (Beamer, Video call). They do not use activities with current technological tools to create new virtual spaces, new interactive activities, collaborative work in communities, artistic pieces designed through software programs or research projects supported by ICT.

The problem of a poor implementation of ICT in the pedagogical competencies of the Visual Arts teachers from University of Atlántico, is the result of their lack of ownership of the potential of these technological tools to enhance their knowledge of new learning experiences in Visual Arts. Teachers perceive ICT in a dynamic and engaging way, considering the tasks and activities that students present, because ICT provide new platforms with a variety of options, so that the students can interact with other communities and design their own environment.

\section{Recommendations}

Based on this research, we can make the following recommendations:

1. Visual Arts teachers need to make changes in their pedagogical models, i.e., those who have worked in classrooms must propose online courses, subjects or blended classes, so that they can improve their pedagogical 
skills supported by ICT and geared towards the generation and deepening of knowledge.

2. Visual Arts teachers need to have access of the technological tools for the development of educational contents.

3. It is required for the creation of technological tools for Visual Arts, so that teachers can select which tools are best for the support of educational contents.

4. Teachers must be trained on how to incorporate ICT in their pedagogical competencies and the use of virtual platforms for virtual education.

5. The faculty must offer rewards for the support and promotion of research projects supported on ICT.

6. University of Atlántico must invest on the implementation of technological and audiovisual resources (electronic board, graphic design software in 2D and 3D) and the implementation of virtual platforms for virtual education.

7. To promote the application of alternative trends in Visual Arts at a national and international level supported by new technologies.

8. Most teachers of Visual Arts should have an appropriate knowledge of ICT competencies in Visual Arts, to teach their pedagogical contents and spread their art to a wider audience by means of modern technologies.

9. Teachers need to work ccollaboratively for the development of research projects supported by technology, scientific posts based on scientific articles, publication of contents in digital repositories and share the contents with other universities abroad.

10. Finally, teachers need a greater appreciation of ICT in order to strengthen their pedagogical activity in the Visual Arts Program at University of Atlántico.

\section{References}

İşman, A. (2011, January) Instructional Design in Education: New Model, The Turkish Online Journal of Educational Technology - TOJET, 10 (1) 136 - 142.

Benson, L., Elliot, D., Grant, M., Holschuh, D., Kim, B., Kim, H., Lauber, E. Loh, S., \& Reeves, T. (2002). Usability and Instructional Design Heuristics for ELearning Evaluation. In P. Barker \& S. Rebelsky (Eds.), Proceedings of World Conference on Educational Media and Technology 2002 (pp. 1615-1621). Association for the Advancement of Computing in Education (AACE).

Clark, R. (2002). Six principles of effective e-Learning: What works and why. The eLearning Developer's Journal, 1-10. Retrieved from http://one-task-at-atime.tripod.com/six.pdf.

Ellis, R. (2004). Down with Boring E-Learning! Interview with E-Learning Guru Dr. Michael W. Allen. Learning Circuits Magazine. Retrieved from http://www.learningcircuits.org/2004/jul2004/allen.htm.

Guerra, M., \& Oviedo, J. (2011). De las telecomunicaciones a las TIC: Ley de TIC de Colombia. [Telecommunications ICT: ICT Act of Colombia] Oficina de la CEPAL en Colombia. Bogotá: CEPAL.

Guilar, J., \& Loring, A. (2008). Dialogue and Community in Online Learning: 
Lessons from Royal Roads University.The Journal of Distance Education / Revue de l'ducation Distance, 22(3), 19-40. Athabasca University Press.

Hung, E. (2013). Medición del impacto de las actividades orientadas al fomento de las TIC en el sector educativo en la Región Caribe Colombiana. Caso Barranquilla y Cartagena. [Measuring the impact of efforts to promote ICT in the education sector in the Colombian Caribbean region. Case Barranquilla and Cartagena ] Universidad del Norte, Universidad Tecnológica de Bolívar y la Corporación Colombia Digital.

Jacka, L., \& Ellis, A. (2010). Virtual arts: visual arts education in the virtual world of Second Life, Australian Art Education, 33(2), special ed.,. 125-139.

Knapp, K.M., \& O'Driscoll, T. (2010). Learning in 3D: Adding a New Dimension to Enterprise Learning and Collaboration. San Francisco: Pfiffer.

Leal, D. (2008) Iniciativa colombiana de objetos de aprendizaje: situación actual y potencial para el futuro [Colombian Initiative learning objects: current status and future potential]. Revista Apertura, 8, 3-8.

María de Hostos, E. (2005). Integración de las Artes al currículo escolar: Proyecto de desarrollo profesional para maestros/as [ Integrating the Arts into the school curriculum: Draft professional development for teachers] Centro de Investigaciones Educativas Facultad de Educación. Universidad de Puerto Rico Recinto de Río Piedras.San Juan, Puerto Rico

International Council for Open and Distance Education (ICDE). Ministry of Higher Education. E-Learning and Distance Education [PDF document]. Retrieved from http://www.icde.org/filestore/Resources/Handbooks/e-

LearningAndDistanceEducation.pdf.

Moore, M. G. (1990). Background and overview of contemporary American distance education. Contemporary issues in American distance education (pp. xii-xxvi). New York: Pergamon Press.

Morales, R. (2011). Modelo de objetos de aprendizaje para la producción y gestión de contenidos educativos [Learning object model for the production and management of educational content]. Revista Chilena de Ingeniería, 19, 2-5.

Nichols, M. (2003). A theory of eLearning. Educational Technology \& Society, 6(2), $1-10$.

Prendes, M., Castañeda, L., \& Gutiérrez, I. (2010). Competencias para el uso de TIC de los futuros maestros [Skills for the use of ICT for future teachers.] Revista Científica de Educomunicación, 35, 175-182.

Peachey, A.; Gillen, J.; Livingstone, D., \& Smith-Robbins, S. (Eds.) (2010). Researching Learning in Virtual Worlds. London: Springer.

Reiser, R. A., \& Dick, W. (1996). Instructional planning: A guide for teachers. Boston: Allyn and Bacon.

Ryan, M. (2008). 16 Ways to Use Virtual Worlds in your Classroom: Pedagogical Applications of Second Life. In Researching Learning in Virtual Environments International Conference (pp. 269-178). The Open University, Milton Keynes, UK. Retrieved from http://www.lancs.ac.uk/postgrad/ryanm2/.

Tavangarian, D., Leypold, M. E., Nölting, K., Röser, M., \& Voigt, D. (2004). Is eLearning the solution for individual learning? Electronic Journal of e-Learning, 2(2), 273-280.

Triacca, L., Bolchini, D., Botturi, L., \& Inversini, A. (2004). Mile: Systematic usability evaluation for e-Learning web applications. AACE Journal, 12(4).

UNESCO (2008). ICT Competency Standards for Teachers. Retrieved from: http://www.oei.es/tic/UNESCOEstandaresDocentes.pdf. 
